\title{
Educational background and access to legal academia
}

\author{
Mark Davies* \\ Sussex Law School, University of Sussex, Brighton, UK \\ *Author email: m.r.davies@sussex.ac.uk
}

(Accepted 25 May 2017)

\begin{abstract}
The focus of this paper is upon the educational background of academic lawyers in England and Wales and the extent to which qualifications from certain institutions may be seen as acting as a proxy for social class. In recent years higher educational background and socio-economic background have been significant topics of research relating to entry to the legal professions and judiciary in England and Wales. There is a relative absence of such research relating to academic lawyers. The research discussed in this paper aims to close that gap. The paper argues that critiques relating to the elite nature of the traditional legal professions in terms of educational background have parallels within the academic legal community, evidenced by a dominance of those educated at Cambridge, Oxford and other Russell Group institutions, with relatively lower proportions of graduates from other sectors, most notably the post-1992 universities. The paper further argues that economic hurdles to entry to an academic legal career are significantly higher than those for other law related careers, potentially exacerbating issues of socio-economic exclusion. The conclusion drawn is that law schools should engage proactively with measures to expand opportunities for entrants into the academic legal community from candidates from a much wider range of educational backgrounds.
\end{abstract}

Keywords: academics; education; class

\section{Introduction}

In the UK, there are various approaches to categorising class. For example, National Statistics Socioeconomic Classification (NS-SEC) defines Class 1 as comprising senior managerial and professional roles and Class 2 as lower managerial and professional occupations. Savage et al adopt a different model - at the top, the 'Elite' class are defined as those with 'high levels of highbrow cultural capital [and] strong social capital, as well as very high levels of household income, savings and house price'. Below the Elite are the 'Established Middle Class' - also with high levels of all three types of capital, but not as high as the Elite. ${ }^{1}$ A number of studies which consider the relevance of socio-economic factors to, for example, university entry or access to certain professions, use geographical origin - postcode data or similar acting as a substitute for more direct measures of class on an individual by individual basis. $^{2}$

Once established in their careers, academic lawyers possess many of the attributes of at least NSSEC Class 2 or Established Middle Class. ${ }^{3}$ However, for the purposes of this paper, what is of more interest is the gaining of entry to this field in terms of background. Study of class background is problematic, definitionally fluid and often based upon research subjects' own accounts of their perceived

\footnotetext{
${ }^{1} \mathrm{P}$ Wakeling and M Savage 'Entry to elite positions and the stratification of higher education in Britain' (2015) 63 Sociological Review 290.

${ }^{2}$ See for example M Savage Social Class in the 21st Century (London: Pelican, 2015) ch 8.

${ }^{3}$ See for example F Cownie Legal Academics: Culture and Identities (Oxford: Hart, 2004) pp 176-177, citing C Wells 'Working out women in law schools' (2001) 21 Legal Studies 116; R Collier 'The changing university and the (legal) academic career - rethinking the relationship between women, men and the "private life" of the law school' (2002) 22 Legal Studies 1. 
class background and/or recollection of parental occupations. ${ }^{4}$ In the light of this, although an imperfect surrogate, educational background is often used as a more readily and accurately measurable criterion, in lieu of self-description or other measure of class or socio-economic background. ${ }^{5}$ As Bourdieu observed, in the context of French higher education, legal academics, especially those in more prestigious universities, tended to come from higher social classes, with appointment and promotion playing an important part in reproducing class distinctions. ${ }^{6}$ In Bourdieu's terms, cultural capital - possession of attributes associated with the dominant culture in society - is not possessed equally and is to an extent dependent upon upbringing. Cultural capital influences access to the most privileged sectors of higher education and, in turn, the educational qualifications attained add to the cultural capital an individual possesses. ${ }^{7}$

The wider climate in which the current research was undertaken has been the focus in recent times on access issues relating to the legal professions, and the omission of the academic legal community from certain aspects of that debate. Leading scholars have produced impressive work about legal academia in the $\mathrm{UK},{ }^{8}$ including a number of outputs with gender or race as a focus. ${ }^{9}$ For example, Cocks and Cownie note the historical dominance of the 'stereotype white middle-class male' in the (what is now) Society of Legal Scholars, and cite Goode's observations from the 1990s that the Society 'is dedicated to equal opportunities ... Yet it remains the case that the number of senior posts held by women and by ethnic minorities is small.' ${ }^{10}$ The engagement with class or socio-economic background within the academic legal community has tended to focus upon self-description and matters such as individual perceptions of 'fitting-in' to a middle-class academic community. ${ }^{11}$ There remains a relative absence of research which parallels the various studies looking at the higher education backgrounds of entrants to other branches of the legal profession and the equality issues this may raise. ${ }^{12}$

This paper aims to take significant steps in closing that gap. The focus considers the extent to which the qualification profile of university law school academics in England might give rise to questions about socio-economic inclusion.

\footnotetext{
${ }^{4}$ In terms of the latter, distinctions may depend upon the subtleties of job description, as well as accuracy of recollection. Parents who are, for example, solicitors, barristers or surgeons may be confidently classified, but within the multi-layered hierarchies of large business organisations job titles may give only a limited amount away about status and seniority. Fiona Cownie, for example, acknowledges, in her 2004 study involving 54 academics in English law schools, the difficulties and disagreements about the nature of class and self-categorisation: Cownie, above n3, pp 176-180.

${ }^{5}$ See for example Sutton Trust Briefing Note: The Educational Backgrounds of the UK's Top Solicitors, Barristers and Judges (June 2005), available at http://www.suttontrust.com/wp-content/uploads/2005/05/Comparison_educational_backgrounds.pdf.

${ }^{6} \mathrm{P}$ Bourdieu (trans Peter Collier) Homo Academicus (Cambridge: Polity Press, 1988) p 84.

${ }^{7} \mathrm{P}$ Bourdieu 'Cultural reproduction and social reproduction' in J Karabel and AH Halsey (eds) Power and Ideology in Education (Oxford: Oxford University Press, 1977) p 487. The latter constitutes one of the three forms of cultural capital identified by Bourdieu - capital in its institutionalised form, such as qualifications and titles. The other two forms are embodied capital, for example regional accent, and objectified capital - for example an expensive car or watch.

${ }^{8}$ For example, A Bradney and F Cownie 'British university law schools in the twenty-first century' in DJ Hayton (ed) Law's Future(s) (Oxford: Hart, 2000) p 13; Cownie, above n 3; A Bradney 'Elite values in the twenty-first century, United Kingdom law schools' (2008) 42 Law Teacher 291; R Cocks and F Cownie A Great and Noble Occupation! The History of the Society of Legal Scholars (Oxford: Hart, 2009).

${ }^{9}$ For example, F Cownie 'Women legal academics - a new research agenda?' (1998) 25 Journal of Law and Society 102; C Wells 'Working out women in law schools' (2001) 21 Legal Studies 116; R Collier 'The changing university and the (legal) academic career - rethinking the relationship between women, men and the "private life" of the law school' (2002) 22 Legal Studies 1.

${ }^{10}$ Cocks and Cownie, above n 8, pp 240-241.

${ }^{11}$ See for example Cownie, above n 3, pp 177-180.

${ }^{12}$ For example, M Galanter and Simon Roberts 'From kinship to magic circle: the London commercial law firm in the twentieth century' (2008) 15 International Journal of the Legal Profession pp 143, 168; H Sommerlad, S Harris-Short, S Vaughan and R Young (eds) The Futures of Legal Education and the Legal Profession (Oxford: Hart, 2015); H Sommerlad 'The "social magic" of merit: diversity, equity, and inclusion in the English and Welsh legal profession' (2015) 83 Fordham Law Review 2325; S Vaughan 'Going public: diversity disclosures by large U.K. law firms' (2015) 83 Fordham Law Review 2301.
} 


\section{The Issues to be Addressed}

The university a person attended, especially for their undergraduate degree, remains highly significant for securing a career in a number of leading professions. In turn, a correlation has been observed between social class and the status ranking of the university attended. ${ }^{13}$ The social capital associated with the 'old boys and girls network', it has been argued, helps graduates from high-ranking institutions to access and rise in key occupations and professions. ${ }^{14}$ As Kirby describes the position, the overrepresentation in many leading occupations of those with particular educational backgrounds 'demonstrates limits to the scope of social mobility in the UK ... Educational background is certainly not the only determinant of a person's views and perspective, but it is an element of this and the homogeneity of sociodemographic backgrounds ... suggests that some groups are being afforded prominence over others. ${ }^{15}$

The historical dominance of certain educational institutions means that senior figures within employing organisations are more likely themselves to be graduates of such institutions. Consciously or subconsciously, these employers may tend to favour candidates in their own image. Decision making in this direction may be further facilitated by the 'soft' skills which candidates from certain backgrounds and certain educational institutions possess. Such skills are not genuinely vital for employment, but facilitate the capacity for employers to define 'talent' in a manner which leads to the recruitment of candidates 'like themselves'.

\section{Socio-economic background and student entry to university}

The latter decades of the twentieth century showed a generally unfavourable picture in terms of the proportion of university students from lower socio-economic backgrounds, with little evidence of improvement during that period. Into the twenty-first century the position has begun to improve, but very slowly and not equally across institutions. ${ }^{17}$ For example, in May 2016 The Office for Fair Access (OFFA) reported that those English higher education institutions which already had a higher proportion of students from under-represented groups were most likely to continue to improve in these areas, whereas institutions, notably high tariff ones such as some Russell Group universities, with low proportions of undergraduates from disadvantaged backgrounds, were progressing more slowly. ${ }^{18}$ In $2015-2016$ only $3.3 \%$ of young people from the most disadvantaged geographical areas were admitted to selective high tariff institutions and, overall, prospective students from the most advantaged backgrounds were over six times more likely than those from disadvantaged backgrounds to be admitted to such institutions. ${ }^{19}$ Universities and Colleges Admissions Service (UCAS) data for 2015 is even more pronounced - for Russell Group universities other than Oxford and Cambridge, students from the most privileged geographical backgrounds were up to 12 times more likely to be admitted compared with those from the most disadvantaged backgrounds. These figures rose to between 14 and 16 times more likely to win places at Oxford or Cambridge. ${ }^{20}$ Data from the

\footnotetext{
${ }^{13}$ A Francis 'Legal education, social mobility and employability: possible selves, curriculum intervention and the role of legal work experience' (2015) 42 Journal of Law and Society 173 at 196; K Purcell, M Morley and G Rowley Employers in the New Graduate Labour Market: Recruiting from a Wider Spectrum of Graduates (Bristol: Employment Studies Research Unit and The Council for Industry and Higher Education, 2002), cited by L Morley 'The X factor: employability, elitism and equity in graduate recruitment' (2002) 2 Twenty-First Century Society 191 at 196.

${ }^{14} \mathrm{P}$ Kirby Leading People 2016 (February 2016) Sutton Trust p 12.

${ }^{15}$ Ibid, p 7.

${ }^{16}$ Ibid, p 14, citing L Ashley, J Duberley, H Sommerlad and D Scholarios A Qualitative Evaluation of Non-Educational Barriers to the Elite Professions (London: Social Mobility and Child Poverty Commission, 2015).

${ }^{17} \mathrm{P}$ Bolton Higher Education and Social Class Standard Note: SN/SG/620 18 June 2010 House of Commons Library.

${ }^{18}$ Office for Fair Access Outcomes of Access Agreement Monitoring for 2014-15, paras 21, 65-66, available at https://www. offa.org.uk/wp-content/uploads/2016/05/2016.04-Outcomes-of-access-agreements-monitoring-1.pdf.

${ }^{19} \mathrm{Ibid}$.

${ }^{20} \mathrm{UCAS}$, available at https://www.ucas.com/corporate/data-and-analysis/ucas-undergraduate-releases/ucas-undergraduatereports-sex-area.
} 
Higher Education Statistics Agency (HESA) have indicated a rise of around 5\% in participants from less advantaged socio-economic backgrounds entering higher education in the period 2004-2015, but with less progress by more elite selective universities compared to their less elite counterparts. Overall, selective universities showed an average increase of less than $2 \%$, with some among them moving in a negative direction in some of the years under consideration. ${ }^{21}$ The Independent Reviewer on Social Mobility and Child Poverty stated that the odds against a child eligible for free school meals ${ }^{22}$ at secondary school being admitted to Oxford or Cambridge were 2,000 to $1 .{ }^{23}$ These disparities cannot be accounted for by the geographical location of some of the more selective universities. Research looking at pairs of universities in the same area has shown significant disparities in the social class of graduates between Russell Group and their post-1992 neighbours. For example, over 50\% of Cambridge University graduates were in the 'elite ${ }^{24}$ social class compared with fewer than $15 \%$ of those from neighbouring Anglia Ruskin University. ${ }^{25}$

Care must be taken not to overstretch conclusions regarding correlation and causation in terms of socio-economic background, university of study and career opportunities. However, as Vaughan notes, secondary data can play a valuable role in the absence of direct information. ${ }^{26}$

\section{The Equality and Access Debate in Higher Education}

As Atherton observes, some, perhaps many, academics will express sympathy to the idea of playing their part in enhancing social mobility. For example, following a Solicitors Regulation Authority (SRA) consultation regarding changing the routes to qualification for future solicitors, a response by the Faculty of Law, University of Oxford included: 'We strongly support the SRA's commitment to improving access to, and diversity in, the profession. ${ }^{27}$ However, a focus on improving social mobility among students tends not to be treated as a priority by academic reward and promotion structures. ${ }^{28}$ Similar observations may be made with regard to the academic community addressing adequately the challenges of increasing social diversity within its own ranks.

The Legal Education and Training Review (LETR) ${ }^{29}$ considers issues of fair access to the legal professions but does not discuss access to the academic legal profession. With regard to legal practice, the report notes that effective fair access policies have the potential to drive up quality and to ensure that

\footnotetext{
${ }^{21} \mathrm{HESA}$, available at https://www.hesa.ac.uk/.

${ }^{22}$ Free school meal eligibility is based upon criteria such as family eligibility for receipt of certain welfare benefits and, as such, is a ready identifier of the poorest families in society. By way of illustration, in January 2016 approximately one in seven pupils were eligible: Department for Education Schools, Pupils and Their Characteristics: January 2016, available at https:// www.gov.uk/government/uploads/system/uploads/attachment_data/file/552342/SFR20_2016_Main_Text.pdf.

${ }^{23}$ Fair Access to Professional Careers: A Progress Report by the Independent Reviewer on Social Mobility and Child Poverty May 2012 p 4, available at https://www.gov.uk/government/uploads/system/uploads/attachment_data/file/61090/IR_ FairAccess_acc2.pdf. See also Panel on Fair Access to the Professions Unleashing Aspiration: The Final Report of the Panel on Fair Access to the Professions 2009.

${ }^{24}$ Defined as part of the 'Great British Class Survey' as the most privileged class in Great Britain. Elites have high levels of all three capitals (economic, social and cultural) with high amounts of economic capital setting them apart. See website available at http://www.bbc.co.uk/science/0/21970879.

${ }^{25} \mathrm{M}$ Savage Social Class in the 21st Century (London: Pelican, 2015) p 238.

${ }^{26}$ In the context of the solicitors' profession, Vaughan notes that direct data regarding the class or socio-economic background of employees is not available, hence the value of secondary data. Vaughan, above n 12, at 2306.

${ }^{27}$ See website available at https://www.law.ox.ac.uk/news/2016-03-10-oxford-law-faculty-responds-consultation-changessolicitors $\% \mathrm{E} 2 \% 80 \% 99$-training.

${ }^{28}$ L Coiffait (ed) Blue Skies: New Thinking about the Future of Higher Education: A Collection of Short Articles by Leading Commentators UK 2014 edn (London: Pearson, 2014) p 18, available at http://pearsonblueskies.com/wp-content/uploads/ 2012/09/4136.BlueSkies_A5_Web.pdf.

${ }^{29}$ J Ching, P Maharg, A Sherr and J Webb (Lead Researchers) Setting Standards: The Future of Legal Services Education and Training Regulation in England and Wales (2013), available at http://www.letr.org.uk/the-report/index.html.
} 
the professions are representative of the society they serve. ${ }^{30}$ Under the heading 'Diversity and the cost of education and training', the report notes that widening participation policies have shown positive results in terms of gender and race representation, but also reinforces other research findings discussed above, that progress in addressing inequalities in terms of the socio-economic origins of the student population has been slow, especially within elite universities, with consequences for professional diversity in terms of social origin. ${ }^{31}$ With regard to the costs of training for prospective barristers and solicitors, the LETR notes that financial risk is a potential barrier to entry, with the greatest obstacles being faced by graduates from non-elite universities and those who have not been able, because of their social or financial circumstances, to build the preferred CV'. ${ }^{32}$ Similar considerations are discussed below with regard to the cost of access to an academic legal career.

Other commentary reinforces the issues the LETR and other research have highlighted regarding the elite nature of the traditional legal professions in terms of educational background, and the slowness of progress in terms of devising and implementing measures to address such an imbalance. ${ }^{33}$ Sommerlad, for example, observes: 'recent years have seen a reinvigoration of archaic signs of privilege, so that it is increasingly difficult for those from "lower" socioeconomic backgrounds and/or low status universities to even enter the profession; conversely, the value of a degree from Oxford or Cambridge has increased. ${ }^{34}$

The ranks of the senior judiciary are also dominated by those who attended 'elite' universities around $75 \%$ overall (an almost identical number to those who had attended a fee-paying school) having attended Oxford or Cambridge, followed by other Russell Group universities at around 20\%. Fewer than $2 \%$ of senior judges attended non-Russell Group universities. ${ }^{35}$

A 2013 survey of barristers found that 32\% attended Oxford or Cambridge, 39\% other Russell Group universities, 12\% other pre-1992 universities and 11\% polytechnics/post-1992 universities and the remainder other 'second wave' universities and overseas institutions. ${ }^{36}$ The Sutton Trust found that $53 \%$ of the partners in 'magic circle ${ }^{37}$ solicitors' practices had attended Oxbridge, with a further $26 \%$ attending what the report called the other 12 top universities. ${ }^{38}$

Vaughan's review of the academic analysis applied to data of this type found a tendency towards conclusions that the favouring of Oxbridge and other 'elite' universities has resulted in a less diverse workforce in terms of other equality measures. ${ }^{39}$

\footnotetext{
${ }^{30}$ LETR para 6.2.

${ }^{31}$ Ibid, para 6.6.

${ }^{32}$ Ibid, paras 6.11-6.12.

${ }^{33}$ See for example Panel on Fair Access to the Professions Unleashing Aspiration: The Final Report of the Panel on Fair Access to the Professions 2009, available at http://webarchive.nationalarchives.gov.uk/+/http://:/www.cabinetoffice.gov.uk/ media/227102/fair-access.pdf; Fair Access to Professional Careers: A Progress Report by the Independent Reviewer on Social Mobility and Child Poverty May 2012, available at https:/www.gov.uk/government/uploads/system/uploads/attachment_ data/file/61090/IR_FairAccess_acc2.pdf.

${ }^{34}$ Sommerlad, above n 12, 2331, citing Galanter and Roberts, above n 12, at 168.

${ }^{35}$ The remaining 3\% were educated abroad. Fair Access to Professional Careers, above n 33, table 3.1 at 32.

${ }^{36}$ Bar Standards Board and the General Council of the Bar Barristers' Working Lives: A Second Biennial Survey of the Bar (2013) p 23, available at https://www.barstandardsboard.org.uk/media/1597662/biennial_survey_report_2013.pdf.

${ }^{37}$ This is an informal but widely used term within legal circles to denote the most prestigious, usually five, solicitors' firms with headquarters in London. They sit at the top of the legal hierarchy in terms of reputation and fee income/earnings per partner. Because of the dominant position of a number of Anglo-Welsh solicitors' firms globally, in turn the magic circle also enjoy high status internationally. For further discussion, see website available at http://www.chambersstudent.co.uk/lawfirms/types-of-law-firm/magic-circle-law-firms.

${ }^{38}$ Sutton Trust Briefing Note: The Educational Backgrounds of the UK's Top Solicitors, Barristers and Judges June 2005, available at http://www.suttontrust.com/wp-content/uploads/2005/05/Comparison_educational_backgrounds.pdf.

${ }^{39}$ Vaughan, above n 12, at 2314, citing L Ashley 'Making a difference? The use (and abuse) of diversity management at the UK's elite law firms' (2010) 24 Work Emp \& Soc 711; L Ashley and L Empson 'Differentiation and discrimination: understanding social class and social exclusion in leading law firms' (2013) 66 Hum Rel 219 at 221; H Rolfe and T Anderson 'A firm choice: law firms' preferences in the recruitment of trainee solicitors' (2003) 10 International Journal of the Legal Profession 315 at 322.
} 
In recent years the legal professions have launched a number of initiatives to address issues of inequality, including socio-economic inequality, which may result from an unduly restrictive approach to recruiting students from a limited number of 'elite' universities. Notable examples of such initiatives are PRIME, ${ }^{40}$ the Pegasus Access Scheme, ${ }^{41}$ curriculum vitae blind and contextual recruitment. ${ }^{42}$ For example, by allowing candidates to present their own narrative at interview, the hope is that this will better allow them to present themselves and their strengths, rather than the focus being on background experiences. This has the potential to reduce tendencies for selectors to favour candidates with similar educational and social backgrounds to themselves. Early reports have indicated that these types of initiative have led to a notable increase in recruitment of students from a wider range of universities and, along with this, appointees from a wider range of backgrounds. ${ }^{43} \mathrm{~A}$ contextual recruitment system offered by Rare, who describe themselves as 'diversity recruitment specialists', ${ }^{44}$ has reportedly been adopted by a number of leading law firms. The system compares the economic and social backgrounds of applicants by drawing from databases of school and college exam results and postcode data. Rare's own analysis has suggested that, if applicants from disadvantaged backgrounds can be persuaded to apply to top firms, use of contextual recruitment can improve their chances of appointment by up to $50 \%{ }^{45}$

In the context of the above discussion, the remainder of this paper considers whether there are similar issues which legal academia needs to address.

\section{Research Methodology Categorizing universities}

Having identified that perceived university status can act as a surrogate for privilege, the follow-on challenge for this project is how then to categorise universities. The numbers of first degree and postgraduate courses in law and related subjects ebbs and flows over time - a snapshot from the Unistats database in October 2016 revealed 135 university or college institutions offering in total over 1,000 courses. These institutions range from the ancient universities, such as Oxford and Cambridge, to relatively new entrants to the field. In terms of other measure, for example newspaper league tables, the number of law faculties typically listed is lower - The Guardian newspaper league table, for example, includes 96 law schools or departments in its 2017 league table for law. ${ }^{46}$

As Savage observes, 'the British are exceptionally skilled at creating hierarchy from diversity'. ${ }^{47}$ In the field of higher education this has resulted in various rankings emerging over the past three decades. Some, such as the Research Excellence Framework (REF) and its predecessor the Research Assessment Exercise (RAE) have a particular focus, and result from government imposition. Others, notably numerous newspaper league tables, are produced for commercial purposes. A third category encompasses rankings produced by organisations such as the Sutton Trust for their own research purposes,

\footnotetext{
${ }^{40}$ PRIME was launched in 2011 as a collaborative approach to social mobility by a group of leading law firms. Around 30 hours of contact time was pledged to each disadvantaged school-age student participant, to help them to develop skills and to inform them about opportunities. See website at http://www.primecommitment.org/.

${ }^{41}$ See website at http://www.pegasus.me/.

${ }^{42}$ The latter has been endorsed by the Law Society, the representative body for solicitors in England and Wales, which has produced a guidance document to facilitate this approach. The Law Society Using Blind and Contextual Processes for the Recruitment of Trainee Solicitors: Encouraging Social Mobility Guidance and Toolkit for England January 2016.

${ }^{43}$ See for example K Hall 'Clifford Chance broadens diversity with 'CV blind' scheme' Law Society Gazette 10 January 2014, available at http://www.lawgazette.co.uk/practice/clifford-chance-broadens-diversity-with-cv-blind-scheme/5039349. fullarticle.

${ }^{44}$ See website at https://www.rarerecruitment.co.uk/index.php\#.

${ }^{45} \mathrm{An}$ impressive uplift if independently verified and if it proves to be sustainable, available at https://www.rarerecruitment. co.uk/news.php?t=news\&c=498\#.V82_yPkrLal.

${ }^{46}$ See website at https://www.theguardian.com/education/ng-interactive/2016/may/23/university-guide-2017-league-tablefor-law. An additional 12 institutions are listed as teaching law but not meeting the criteria to be included in the main table.

${ }^{47}$ Savage, above n 25, at 232.
} 
or ones emerging from broader social surveys. ${ }^{48}$ While methodologies differ, there is a significant amount of consistency between many UK-based ranking systems, such that the Russell Group universities tend to dominate the higher-rank positions, and universities from the post-1992 sector the lower-rank positions.

Oxford and Cambridge universities typically form a category alone, as on most league table measures they appear at or around the top. There is then scope for debate beyond this. Pre-1992 and post-1992 institutions are two further potential categorisations on the basis of league table rankings. ${ }^{49}$ Within the pre-1992 sector the self-appointed members of the Russell Group are used in some studies as key examples of selective or elite universities. Drawing from the Great British Class Survey, Wakeling and Savage note the dominance of Russell Group graduates in advantaged economic positions - such graduates being considerably more likely to be found in the Elite class and in NS-SEC class 1 than those from other institutions. ${ }^{50}$ The Sutton Trust rank of the top 30 universities in the UK also sees the Russell Group dominate.

Drawing from this environment, and acknowledging that there will be some scope for debate and disagreement about categorisation, the approach used in the current study is to adopt four categories: Oxford and Cambridge (Oxbridge); other Russell Group; Pre-1992 non-Russell Group; and post-1992.

\section{Data collection and anonymity}

In order to consider the recruitment patterns of academic faculty within English university law schools ${ }^{51}$ this study focuses on a sample consisting of Oxford and Cambridge, eight other English universities from the Russell Group, eight from non-Russell Group pre-1992 English universities and eight from post-1992 English universities. ${ }^{52}$ In terms of approximate percentage representation, using The Guardian newspaper league table entries for 2017, eight constitutes just under $50 \%$ of English Russell Group law schools and around 50\% of other pre-1992 English law schools. As a proportion of all post-1992 English law schools, eight represents around $18 \%$.

The selection of the sample for each category was chosen to reflect a reasonable geographical spread. ${ }^{53}$ Only those staff members for whom meaningful data could confidently be identified were

\footnotetext{
${ }^{48}$ An example of the latter is developed from the findings of the Great British Class Survey, ibid at 242-243.

${ }^{49}$ The 'post' 1992 descriptor relates to the date point at which a number of non-university higher education institutions, mainly polytechnics, were granted university status. In their former guise a large proportion of these institutions had been teaching students to degree level and in some instances beyond for many years before 1992. For a more detailed discussion of the nature and legal status of different types of higher education institution in the UK see D Farrington and D Palfreyman The Law of Higher Education (Oxford: Oxford University Press, 2nd edn, 2012).

${ }^{50} \mathrm{P}$ Wakeling and M Savage 'Entry to elite positions and the stratification of higher education in Britain' (2015) 63 Sociological Review 290 at 303.

${ }^{51}$ For ease of reference the term 'law school' is used irrespective of whether the actual unit title was school, department, faculty or other name.

${ }^{52}$ For readers unfamiliar with these UK classifications, the Russell Group is a self-selected group, established in 1994, currently consisting of 24 research-intensive universities. Twenty are based in England, with the remainder in Northern Ireland, Scotland and Wales. All Russell Group members are also pre-1992 universities. The Universities of Oxford and Cambridge are Russell Group members, but for the purposes of this paper will be considered as a category on their own. As previously noted, in 1992 a number of higher education institutions, notably polytechnics, acquired university status as a result of the provisions of the Further and Higher Education Act 1992. In this paper these are referred to as post-1992 universities, whereas those institutions which had university status before the provisions of the Further and Higher Education Act 1992 came into force will be referred to as pre-1992 universities.

${ }^{53}$ Three Russel Group institutions from the north of England, two from the Midlands, one from London and two from the south of England; one pre-1992 institution from the north of England, two from the Midlands, one from London and four from the south of England; one post-92 institution was from the north of England, three from the Midlands and four from the south of England. In order to preserve anonymity these geographical categorisations are loosely defined. Consideration was given to further filtering based, for example, on league table rankings, but the proliferation of league tables, each making their own particular use of data and how they should be weighted, risked introducing a degree of complexity which was deemed unnecessary for the purpose of the study.
} 
included. Therefore, for each law school the inclusion list was not $100 \%$, but in all cases was a majority, and in many cases a significant majority, of all relevant staff. The nature of qualifications and experience was such that for a few individuals some attributes were counted more than once, for example if an individual had two first degrees or two master's degrees. Instances of this occurring were relatively few, but the inclusion of this data means that numbers do not total $100 \%$. Similarly, because each attributable category, eg a doctorate, was not possessed by every staff member, numbers do not total $100 \%$. The data presented are therefore intended to give a sense of meaningful patterns, which can be compared between institutions, rather than the basis for ultra-precise data analysis. ${ }^{54}$

The data collected are publicly available and so the universities considered could have been named. However, the decision was made to present the findings in an anonymised form to avoid potentially distracting discussions about subtle differences between individual universities within and between categories, when the intended focus of the research is on considering overarching patterns. ${ }^{55}$

To maximise consistency, the study focused on staff with career profiles which indicated that their appointment with the university in question was their main occupation. So, for example, visiting scholars, doctoral students undertaking some teaching, and emeritus academics were omitted. In terms of categorisation of qualifications and previous academic employment, Oxbridge, Russell Group, other pre-1992 and post-1992 descriptors were used along with one covering non-UK qualifications and employment. For qualifications and employment which predate the creation of the Russell Group or the transition to university status of what are now post-1992 institutions, these categorisations are maintained for ease of reference. The focus was on English universities to allow for best comparison with research looking at English solicitors' firms and barristers' chambers. ${ }^{56}$

\section{Key findings from the study}

The full tables of findings from which the following observations are drawn are presented in 'Appendices 1-4'.

\section{First degrees}

Close to 50\% of Oxbridge law academics are graduates of Oxford or Cambridge universities, with the next highest proportion, $31 \%$, having a first degree from overseas. Of the graduates from other UK universities who made it onto the Oxbridge faculty list, only 3\% were non-Russell Group.

From the non-Oxbridge Russell Group sample, 50\% of academic law staff have first degrees from the Russell Group (including Oxford and Cambridge), with the next highest proportion, 32\%, obtaining their first degree overseas. Fifteen percent of Russell Group academics began their higher education in the UK outside the Russell Group, with $2 \%$ obtaining an undergraduate degree from a polytechnic/ post-1992 institution.

The pre-1992 (non-Russell Group) sample included a significant number of Russell Group (including Oxford and Cambridge) first degree holders, 31\%, although the largest percentage, $41 \%$, obtained

\footnotetext{
${ }^{54}$ In this regard, useful lessons were drawn from Epstein and Martin regarding the importance of considering the balance between clarity and necessary degree of precision in data presentation. L Epstein and AD Martin 'Quantitative approaches to empirical legal research' in P Cane and HM Kritzer (eds) The Oxford Handbook of Empirical Legal Research (Oxford: Oxford University Press, 2010) pp 901-925 at 917-924.

${ }^{55}$ It is acknowledged that as a two-member set, the veil of anonymity covering Oxbridge 1 and Oxbridge 2 is rather thin. However, given the importance of Oxford and Cambridge in much of the wider literature regarding equality, access and career opportunities, it would have removed the opportunity for potentially important findings had these two institutions been included (or not) as anonymous members of the larger Russell Group set.

${ }^{56}$ The two largest 'for-profit' providers of legal education, BPP University and the University of Law, were excluded because of the relative newness of their undergraduate provision and their longer-standing dominance in postgraduate professional education, which at present largely sets them apart from the other universities in the study.
} 
their first degree outside the UK. Twenty-one percent were graduates of pre-1992 (non-Russell Group) universities, with 5\% obtaining their first degree from a polytechnic/post-1992 institution.

Within the post-1992 sector, the presence of Russell Group graduates (including Oxford and Cambridge) was also high, at 37\%. Graduates from a polytechnic/post-1992 institution were the next largest category in the post- 1992 sector, at $27 \%$, followed by graduates from institutions outside the UK, at 22\%, and then pre-1992 (non-Russell Group) universities, at $16 \%$.

Contextualising these figures in terms of total law graduate numbers, Oxbridge accounts for around $2 \%$, the Russell Group 20\%, non-Russell Group pre-1992 universities 22\% and post- 1992 universities $56 \%{ }^{57}$

Overall, in terms of international diversity measured by first degree institution, English law schools are well represented, with $20-40 \%$ of non-UK first degree holders across different parts of the sector. However, when it comes to graduates from within the UK, the Russell Group (including Oxford and Cambridge) dominates. There appear to be comparatively poor prospects for those who start their UK higher education outside the Russell Group building an academic career in that sector. This lack of opportunity is especially marked for someone beginning their higher education at a post-1992 institution, such a person having a marginal chance of building an academic career at Oxbridge, the Russell Group or other pre-1992 institution. Even with the post-1992 sector itself, graduates from that sector are in a minority.

Based upon this data, similar concerns can be levelled at the academic legal profession as have been levelled at barristers, solicitors and the judiciary - significant weight hangs upon 'A' level grades or the equivalent, ${ }^{58}$ as the university type that these 'purchase' access to is likely to very strongly influence future academic career opportunities. In turn, this then gives rise to concerns about the effect of socioeconomic/class background on the nature of pre-higher education and the chances it provides for those from poorer backgrounds to effectively compete for entry into Oxbridge or the remainder of the Russell Group.

\section{Postgraduate study}

While a significant majority of academics included in the study had an identifiable first degree, the position for master's and above was more mixed. A number of academic lawyers had doctorates but had progressed to doctoral study directly from their first degree without a master's degree. Some, especially among the more experienced academic cohort, had not pursued doctoral-level study. A few now senior academics had entered the role directly from first degree study, acquiring no further formal qualifications. In this environment, information about institutions of postgraduate study was less useful for determining patterns than information about first degrees.

It is also acknowledged that at postgraduate level there will be a likely drift by applicants towards institutions which are perceived to be more research focused. This can lead to arguments of the type that postgraduate qualifications from certain institutions are more highly represented among the academic community because those institutions produce the highest proportion of postgraduates. However, even from this perspective there is identifiable overrepresentation, albeit less marked than for first degree data. For example, Oxford and Cambridge combined produce around 3-4\% of law postgraduates, yet, as discussed below, account for far higher proportions within most sectors of the academic legal community. ${ }^{59}$ The extent to which graduates from different types of institution progress to postgraduate study may also have relevance, if students from disadvantaged backgrounds, having

\footnotetext{
${ }^{57}$ Precise data will vary over time in terms of the ebbs and flows of law graduate numbers in any particular year. The data presented are intended to be illustrative of the comparative position and draw from a combination of HESA, Law Society and UCAS data for a sample 5-year period, 2009-2014.

${ }^{58}$ See for example Ching et al, above n 29, at para 6.26, and associated Discussion Paper 02/2011 regarding the influence of a range of cultural and economic factors on performance in public examinations such as A levels.

${ }^{59}$ In the absence of a centralised admissions process comparable to that for undergraduate degrees, postgraduate data are more difficult to identify. However, a reasonable estimate can be made by comparing data made available by Oxford and Cambridge themselves, and overall statistics for postgraduate law study produced by the HESA.
} 
secured access to less high status universities for their first degree, then face greater economic obstacles than their more socio-economically privileged counterparts when considering postgraduate study.

\section{Master's degrees}

Master's degrees or equivalent from the Russell Group (including Oxford and Cambridge) dominate across all of the university sectors studied.

From those for whom this information could be identified, $41 \%$ of the Oxbridge academics have Oxbridge master's ${ }^{60}$ and $6 \%$ have master's degrees from other Russell Group universities. Twentysix percent of Oxbridge academics had obtained master's degrees overseas, with fewer than $2 \%$ having non-Russell Group UK master's degrees.

From those for whom this information could be identified, almost $14 \%$ of the non-Oxbridge Russell Group academics have master's degrees from Oxbridge, almost 32\% have Russell Group master's and $20 \%$ overseas master's degrees. Fewer than $8 \%$ have master's degrees from non-Russell Group UK universities.

In the non-Russell Group pre-1992 sample, from those for whom this information could be identified, 7\% have Oxbridge master's degrees, 25\% have master's degrees from other Russell Group universities, $18 \%$ have master's degrees from the pre-1992 sector and around $23 \%$ from overseas. Only $2 \%$ have master's degrees from the post-1992 sector.

In the post-1992 sample, from those for whom this information could be identified, almost 5\% of academics have master's degrees from Oxbridge, 23\% from the Russell Group and 11\% from other pre-1992 universities. Fourteen percent have master's degrees from the post-1992 sector and almost $13 \%$ from overseas.

\section{Doctorate degrees}

From those for whom this information could be identified, $47 \%$ of Oxbridge academics have Oxbridge doctorates, $4 \%$ have doctorates from other Russell Group universities, $11 \%$ from overseas and fewer than $1 \%$ from other UK universities.

Among the Russell Group academics, from those for whom this information could be identified, $11 \%$ have doctorates from Oxbridge, 39\% from the Russell Group, 15\% from overseas and 13\% from other UK universities.

From the pre-1992 sample, from those for whom this information could be identified, $7 \%$ have doctorates from Oxbridge, 28\% from the Russell Group, 24\% from other pre-1992 universities, 17\% from overseas and fewer than $2 \%$ from a post-1992 university.

From the post-1992 sample, from those for whom this information could be identified, $4 \%$ have doctorates from Oxbridge, 19\% from the Russell Group, 11\% from other pre-1992 universities, 6\% from overseas and 5\% from a post-1992 university.

\section{Qualification inflation}

The relevance of this section draws from debates within the legal professions about competence standards and minimum levels of qualification necessary for professional recognition. For example, recent debates relating to solicitors have addressed the possibilities of reductions in qualification periods as mechanisms for improving equality of access. ${ }^{61}$

\footnotetext{
${ }^{60}$ The Oxbridge approach to upgrading, without further study, a first degree to master status in certain circumstances was ignored. The Oxford Bachelor of Civil Law (BCL) was included in the count of master's level degrees.

${ }^{61}$ See for example Legal Services Board recommendations that education and training requirements should be set at the minimum level necessary to ensure competence (see Outcome 3 at http://www.legalservicesboard.org.uk/what_we_do/regulation/pdf/20140304_LSB_Education_And_Training_Guidance.pdf ) and SRA proposals regarding the possible introduction of a Solicitors Qualifying Exam (SQE), website available at http://www.sra.org.uk/sra/news/press/case-SQE-strong.page.
} 
In recent decades the time commitments required to qualify as a barrister or solicitor have remained consistent - a qualifying law degree or equivalent, a one-year full-time (or equivalent parttime) postgraduate professional course plus a period of apprenticeship (one year for barristers, two years for solicitors). Translated into terms of costs to be borne by a prospective qualifier, ignoring what help with funding may be available from grants, charities, future employer contributions etc, this equates to four years of tuition fees plus living expenses. The final apprenticeship stage is funded by means of salary or equivalent by the employing body - most commonly a solicitors' firm or barristers' chambers. ${ }^{62}$ For legal academia there is no equivalent formal qualifying route, as there is no professional body akin to the Bar Standards Board (BSB) or SRA to set a minimum standard. What is required is entirely dependent upon what individual employing universities look for. From the perspective of accessibility, the purpose of this section is to consider whether, in the absence of a formally defined qualification route for academic 'professional' status, there has been an increase over time in the amount of time and money prospective academics have to invest in their education and training to secure the chance to realistically compete for a position in a university law school.

For the purposes of this section, the academic profiles studied were divided into three categories: long experience, defined as 15 years or more academic work experience or equivalent; ${ }^{63}$ mid-career, defined as 5 to 14 years' work experience; early career, defined as 4 or fewer years of experience. ${ }^{64}$

Where there was an indication that an academic was pursuing but had not completed doctoral study, they were not included in either the doctorate or no-doctorate categories. Occasionally, an academic had more than one doctorate, which boosted the doctorate figures slightly. Honorary doctorates were not counted. In a few cases where it could not be ascertained with certainty whether or not a doctorate was honorary, these were left out of the doctorate count but the academic was not counted in the no-doctorate category either. For these reasons, the doctorate/non-doctorate count does not equal $100 \%$.

The findings demonstrate some inflation over time in the educational requirements necessary to commence an academic legal career. Around $18 \%$ of long-experience academics in the nonOxbridge Russell Group sector were identified as not having a doctorate, with slightly fewer, 17\%, in other pre-1992 universities. The figures are even more marked among Oxbridge academics, almost a quarter not having a doctorate, and post-1992 academics, almost two-fifths of long-experience academics not having a doctorate. Many of these long-experience academics, across the sectors, were in a promoted position up to and including full professorial status, suggesting no obvious historical career obstacles arising from the absence of a doctorate.

In the 5-14 year group the numbers with no doctorate were significantly lower, well under 5\% across all of the pre-1992 sectors and under $10 \%$ in post-1992 institutions.

For academics in the most junior group, the prospect of appointment without a doctorate had almost vanished across the pre-1992 sectors and is under 5\% in the post-1992 sector.

In terms of drawing conclusions from these findings, it is important to highlight that, especially among the pre-1992 university sectors, doctoral-level qualifications have been important throughout the timeline under consideration. Even among the longer-experience category a significant majority had doctorates. In equality of access terms, this means that legal academia has long been the most

\footnotetext{
${ }^{62}$ Historically, the solicitors' profession, by far the largest of the Anglo-Welsh legal professions, has required the payment of minimum salaries. This requirement was removed by the Solicitors Regulation Authority in 2014, although the Law Society has continued to recommend that firms pay a minimum salary. For 2016 the Law Society recommended a minimum of $£ 18,547$ for trainees outside London and $£ 20,913$ in London. Actual salaries can be far higher, depending upon the market conditions within which particular firms operate. Trainee salaries of $£ 40,000$ and upwards are not uncommon in large London commercial firms.

${ }^{63}$ For most of the participants all or almost all of this experience was in academia, but the definition was made slightly broader to include the few, for example, who had spent a considerable period in legal practice. Experience rather than seniority in terms of job title is used as the measure to avoid problems which might otherwise have arisen from the fact that some institutions had proportionately fewer professorial or readership posts than others.

${ }^{64}$ For all definitions, experience undertaking tuition as a doctoral student or similar was not included.
} 
time-consuming and potentially expensive of the professional legal occupations - up to six or seven years (the exact time depending upon factors such as time taken to complete a doctorate and whether a master's degree has been obtained prior to doctoral study) of education, all or most of which has to be funded, before significant salaried academic employment can be obtained. ${ }^{65}$ What appears to have changed in legal academia in more recent years is the opportunity to step onto the substantive salaried career ladder at a significantly earlier educational point. In the past it was reasonably possible to access an academic legal career after first degree or master's degree study; it appears to be a highly improbable, near to impossible even, prospect today.

Further comparing this with the usual routes to legal practice, an extra two to three years of study time has to be funded. Based upon cost of living indices and a selection of universities' own estimates to inform students about such costs, living expenses are likely to be in the region of $£ 10-12,000$ per annum and fees in the region of $£ 5,000$ per annum or higher. In total, the fees and living expenses for these extra years of study will exceed $£ 40,000$. If average salary lost during this extra time is also factored in, then an additional $£ 35,000$ - $£ 60,000$ or more can be added. ${ }^{66}$ If the assumption is made that many doctoral students will be offered a limited amount of part-time teaching, then around $£ 3,000$ $£ 4,000$ per annum may be deducted from these costs. The likely realistic scenario, therefore, for a prospective academic without funding support is that they will have to find around $£ 30,000$ more than their equivalent who pursues the solicitor or barrister practitioner route, a figure which may double or even treble once loss of earnings during the extra study time is factored in.

It is important to note that this issue is not specific to academic lawyers; the whole of academia would benefit from reviewing the potential socio-economic impact of its qualification requirements. Some commentators have argued that the historical absence of a doctoral requirement for academic lawyers marginalised law compared with other disciplines, and that law has simply been playing catch-up. $^{67}$

For the purposes of this paper, the focus is on law schools, the comparisons between legal academia and the legal professions and, as an aside, the moral authority which the academic legal community may or may not possess to criticise solicitor, barrister and judicial recruitment practices. Had, for example, solicitors or barristers sought to reintroduce the long-defunct practice of requiring trainees to pay a premium for the privilege of being trained, there would, almost certainly, have been robust questioning and critique from within academia about fairness, access and equality. It appears that legal academia has moved in the direction of increasing hurdles to access largely without the internal critical scrutiny - of matters such as actually necessary minimum educational requirements to undertake the academic role and economic and other support mechanisms to facilitate equality of access which many within academia would apply externally. In this regard, taking a lead in equality terms from which others within the academic community might learn could have presented a better

\footnotetext{
${ }^{65}$ It is acknowledged that funding opportunities are available for doctoral study, but historically these have been highly competitive, and law students have usually been in competition with applicants from across a number of other academic disciplines. Recent developments in government-supported postgraduate loans may provide enhanced opportunities for higher study into the future, but as loans they still place prospective academics at a significant economic disadvantage - increasing their overall debt levels when their equivalents undertaking a period of recognised training (formerly called a training contract) to qualify as a solicitor or pupillage to complete their training as a barrister will be receiving free training and a salary or equivalent. Many law schools provide paid teaching hours for some of their doctoral students but, in terms of guaranteed income and overall value, these arrangements tend to be far less generous than the earning capacity of trainee solicitors or pupil barristers.

${ }^{66}$ These figures can be calculated from average graduate salary data, available from, for example, Department for Business, Innovation and Skills Graduate Labour Market Data. Law-specific figures can be elicited from the Law Society minimum recommended trainee salary figures discussed earlier, and from specific trainee/pupil and recently qualified earnings data for solicitors and barristers often featured in law specific news sources. Similarly, from earnings data collected by professional regulatory and representative bodies such as the SRA, BSB, Law Society and Bar Council.

${ }^{67}$ WL Twining, 'Goodbye to Lewis Eliot: the academic lawyer as scholar' (1980) Journal of the Society of Public Teachers of Law 2.
} 
approach for the legal academy than seeking to 'catch up' with a wider university career model which arguably was and remains in need of reform.

\section{Institutional mobility}

For this aspect of the study the nature of the data available did not allow for consistent identification of the order of career movement. In some cases it was only possible to identify that a particular academic had worked at particular other institutions, but not the order of such moves other than, of course, their current institution being the last move up to the point the data were collected. The data as presented indicate instances of movement, hence some individuals may have changed employer a number of times, others not at all.

Least likely to have worked elsewhere are Oxbridge academics. ${ }^{68}$ Of those who had worked elsewhere, the largest category were within the Russell Group, with very few examples of Oxbridge academics having previously worked at non-Russell Group UK universities. Examples of prior overseas work experience were also small in number. The overall impression of Oxbridge in this regard is one of largely recruiting from within and, when venturing outside to recruit, mainly favouring the Russell Group.

The next lowest number of academics to have moved between institutions were those in post-1992 universities. In the light of other findings from this study, one possible explanation is a relative lack of opportunity to move, especially to institutions outside the post-1992 sector.

Among the non-Oxbridge pre-1992 institutions there is evidence of more significant movement. A small proportion, $8 \%$, of instances involved previous work experience at Oxbridge. Around $26 \%$ of instances were at non-Russell Group pre-1992 universities. The largest proportion, around 38\%, of employment instances involved movement within the Russell Group. There was a small proportion, around 9\%, of previous experience instances in the post-1992 sector and 12\% abroad. These findings present the possibility that institutional, and associated geographical, mobility is required in order to advance within both Russell Group and non-Russell Group pre-1992 sectors. In social mobility terms this may have significant implications for those with restricted socio-economic capital, perhaps limited family resources, as well as for those with current childcare or similar responsibilities.

\section{Professional qualifications}

Becher and Trowler observed that, whereas acquiring a doctorate was more or less obligatory for 'pure' academic disciples, for more vocational ones such as law a professional qualification offered an alternative route and, indeed, offered a safety net of greater employability should an academic career not work out. ${ }^{69}$ As discussed above, given the increased requirement for a doctorate for law academics in recent years, a practising qualification as well as a doctorate indicates even greater investment of time and money. Some of those with practitioner qualifications fell into the no-doctorate category, but many did not and no particular patterns were observed in this regard.

Almost $30 \%$ of the Oxbridge academics are qualified as barristers, solicitors or to practise law in an overseas jurisdiction. The figure for the Russell Group sample is 35\%, almost 37\% for other pre-1992 institutions and 55\% in post-1992 universities. When looked at alongside the no-doctorate data, the post-1992 institutions appear to be the ones which continue to most closely fit the Becher and Trowler observations - perhaps reinforcing ideas that post-1992 institutions are more likely to be the ones which focus less on research and pay more attention to providing an education with some input from those with practising experience. They are also the institutions which are more likely to

\footnotetext{
${ }^{68}$ Account was taken of moves between Oxford and Cambridge, but not of moves between colleges within Oxford or Cambridge.

${ }^{69} \mathrm{~T}$ Becher and PR Trowler Academic Tribes and Territories: Intellectual Enquiry and the Culture of Disciplines (Buckingham: Open University Press, 2nd edn, 2001) p 134.
} 
offer the vocational stage of legal education - currently the Legal Practice Course and/or the Bar Professional Training Course - so recruitment of staff will need to take this into account. ${ }^{70}$

\section{Conclusions}

\section{Qualification equivalence}

It has been observed that more or less subtle ranking and status ordering have long been rife within UK higher education. ${ }^{71}$ Applying this to law schools, it would be naive to assume that there is general agreement within legal academia that equivalent level qualifications from all institutions are of identical quality, although there will be debate about the detail of ranking order. This mirrors longstanding assumptions among employers from legal practice, assumptions which have been challenged by research from the Sutton Trust and elsewhere and which recently have begun to be addressed from within legal practice. It is in this latter regard especially that academic law schools should be strongly motivated to look at their own staff recruitment procedures and practices for inappropriate obstacles and hidden biases. External assumptions about university status and quality are drawn from a variety of, sometimes conflicting, sources of information and are made by non-experts in the field of higher education. Within academia the position should be different. Not only because academics possess greater knowledge and expertise regarding the institutional world they are in, but more importantly because they also generally accept, in the sense that it is rarely subject to open and robust challenge, a rhetoric of equality. Universities are subject to Quality Assurance Agency for Higher Education (QAA) provision, and academics as part of their professional roles comply with these provisions and, at times, perform roles to ensure that others comply. A notable example in this respect is the role of external examiner ensuring, inter alia, comparability of standards:

External examiners provide feedback to the degree awarding body on the comparability of standards and student achievement. This feedback is based on their experience of other higher education providers (whether as a member of staff, external examiner or other role). ${ }^{72}$

As academics from across the law school sectors considered in this paper externally examine each other's degrees, then it would be problematic to justify a lack of equivalence of such qualifications when making selections for academic appointments. Arguments have been advanced for a possible lack of equivalence, making many recruiters:

wary of recruiting from less well-known 'brands', thus entrenching the barriers faced by 'nonnormative' (or maybe non-traditional) students. ${ }^{73}$

Even if this line of reasoning is followed, it is disappointing to find that law schools may be lagging behind their practitioner counterparts in addressing changes to recruitment practices which seek to look behind institutional 'brands'.

\section{Engaging with potential bias}

The nature of this research project is not such that it seeks to allege conscious bias towards or against applicants to academic legal positions from those who have qualifications from certain types of

\footnotetext{
${ }^{70}$ In numerical terms, for example, most LPC places are provided by the 'for profit' providers, BPP University and the University of Law. However, there are 16 post-1992 English law schools which also offer the LPC. In contrast, there are only two pre-1992 English law schools still in the LPC market.

${ }^{71}$ Becher and Trowler, above $\mathrm{n} 69$, at 81.

${ }^{72}$ QAA UK Quality Code for Higher Education - Chapter B7: External Examining, p 10, available at http://www.qaa.ac.uk/ en/Publications/Pages/Quality-Code-Chapter-B7.aspx.

${ }^{73}$ A Sanders, 'Poor thinking, poor outcome? The future of the law degree after the Legal Education and Training Review and the case for socio-legalism', in Sommerlad et al, above n 12, at 150-151.
} 
university. Nor does the methodology extend to seeking to identify comparative numbers of applicants for academic law posts with qualifications from different types of institution and their relative success rate. That would require gaining access to the confidential data relevant to recruitment exercises and would pose significant data protection challenges in terms of individual applications. However, this paper does draw parallels with problems of under-representation within the practising legal professions, problems which should be addressed. An easy to implement experimental initiative would be modified application processes which encourage applicants with qualifications from a full range of academic institutions to apply, and which in turn removes information relating to school and degree awarding institutions from the view of those involved in the shortlisting process. Rethinking what might replace or supplement traditional interviews to best ensure that strengths from candidates from a diversity of backgrounds can be best and most fairly assessed would also be worth experimenting with. An example drawn from legal practice is retaining an interview model, but with interview panel members being distinct from the shortlisting panel and the interviewers not having sight of the application form and references, encouraging maximum focus upon the skills and knowledge required for the role. Ultimately, the best model suited to academia is likely to be one which draws from tried and tested practice in other fields, while adapting and adding features as appropriate. ${ }^{74}$

\section{Qualification Inflation}

Potentially more challenging than adapting recruitment and selection procedures would be initiatives to address the qualification inflation which appears to have occurred within legal academia in recent decades. Six or seven years of costly education places academia at the high end of professional qualification within the UK, a position compounded by an extremely competitive environment to secure an academic position at the end of this. ${ }^{75}$ This qualification timescale is not specific to law in universities, although more noticeable because law has relatively recently shifted in the direction of doctoral-level education being essential. This challenge of accessibility is therefore faced by academia more generally, but it would be to the credit of law faculties if they took a lead with regard to, for example, considering how doctoral-level education, if now truly essential for academic law roles, could be incorporated into the early years of a salaried career comparable with postgraduate apprenticeship models reflected by

\footnotetext{
${ }^{74}$ In the context of applications and shortlisting, an example of how this can be applied even at the highest legal level is illustrated by the Spring 2017 recruitment process for new Supreme Court Justices. In a stated attempt to increase diversity, the application pack, after setting out the minimum eligibility requirements as prescribed by the Constitutional Reform Act 2005 and Tribunals, Courts and Enforcement Act 2007, proceeds by means of 'Criteria for appointment' expressed in terms of: ' 1 . Intellectual capacity, knowledge and expertise ... 2. Judicial and Personal qualities ... 3. Understanding and fairness ... 4. Communication skills...' (page 6), rather than specific qualifications, available at https://www.supremecourt.uk/docs/judicial-vacancies-2017-information-pack.pdf. At the time of writing, it remains to be seen what impact this approach may have on the make-up of the current white, predominantly male, fee-paying school, Oxbridge dominated Supreme Court but, on paper at least, it illustrates that with careful consideration attempts can be made to address long-standing hindrances to equality.

${ }^{75}$ Longitudinal research studies have found that fewer than $50 \%$ of social science and humanities doctoral graduates secure employment in higher education teaching and/or research roles - see for example C Ball, T Vorley, T Hughes, R Moreton, P Howe and T Nathwani The Impact of Doctoral Careers: Final Report (Leicester: CFE Research, November 2014), available at http://www.rcuk.ac.uk/documents/skills/timodcfullreport-pdf/. For examples of more discursive pieces discussing the challenges faced by those wishing to secure and develop an academic career, see R Gill 'Breaking the silence: the hidden injuries of neo-liberal academia' in R Ryan-Flood and R Gill (eds) Secrecy and Silence in the Research Process: Feminist Reflections (London: Routledge, 2009) p 228; 'Academics anonymous: so many PhD students, so few jobs' The Guardian May 2014, available at http://www.theguardian.com/higher-education-network/blog/2014/may/23/so-many-phd-students-so-few-jobs. In contrast, retention rates of newly qualified solicitors at the firms with which they trained ranges from $75 \%$ to around $90 \%$, with some of those not being retained by their training firm securing a post-qualification position elsewhere. See website at http://www.chambersstudent.co.uk/where-to-start/newsletter/trainee-retention and Law Society annual statistical data at http://www.lawsociety.org.uk/support-services/research-trends/annual-statistics-report-2015/. Overall, drawing from data of this type, it can be concluded that a majority of doctoral graduates will not secure a university academic role, whereas a very significant majority of trainee solicitors will secure a practice position on qualification.
} 
training contracts or pupilages within legal practice, or equivalent models used for accountancy and some other professions.

\section{Overall conclusions and the widening participation debate}

The most successful English universities are among some of the highest status in the world, measured by a number of internationally focused league tables now published. This status can only be maintained if they compete effectively in a market for excellent staff. The same arguments apply to the most successful English solicitors' firms and top-performing barristers, who also enjoy international reputations and a client base reflecting this. The observations in this paper are not, therefore, about watering down quality but rather are about ensuring that mechanisms for recruiting the genuinely best candidates are not tainted by outdated practices and historical inertia.

It has been argued that widening participation should be part of an extensive 'dialogue concerning the raison d'être of universities in the twenty-first century'. ${ }^{76}$ Based upon the findings of this research, it might be uncomfortable to recognise that the observations by Sommerlad that there is continuing evidence of 'archaic signs of privilege' in terms of entry to the legal professions has close parallels within legal academia. ${ }^{77}$ Similarly, her observations that 'conceptualizations of merit' are 'rooted in the contemporary system of social stratification and the criteria or standards which encompass concrete monuments to socially accepted subjective preference'. ${ }^{78}$ Merit becomes determined by conventions which are shaped by historically determined category-based power hierarchies. ${ }^{79}$ In terms of this research, hierarchies revolving around perceptions of university status.

In terms of ways forward, the legal professions and those responsible for judicial appointments have been proactive in recent years in terms attempts to increase diversity. University law schools increasingly make use of statements in staff recruitment literature encouraging those from underrepresented groups to apply, but class and educational background remain largely absent from such equality initiatives. Unlike solicitors and barristers, academic lawyers lack an overarching professional body. There is no equivalent of the SRA or BSB to consult publicly about minimum necessary competence standards, to consider requisite qualifications or to debate minimum salaries at certain points along the training path. The Society of Legal Scholars and Committee of Heads of UK Law Schools might be seen as having the potential to occupy representative roles similar to the Law Society for solicitors or Bar Council for barristers. Occupying such roles, they have the potential to support and encourage CV-blind recruitment and to encourage other forms of contextual selection. Similarly, they can consider encouraging a more clearly structured career track where the best first-degree graduates, from any university sector, are provided with the opportunity to step onto a funded track to academia.

\footnotetext{
${ }^{76} \mathrm{DW}$ Thompson 'Widening participation and higher education: students, systems and other paradoxes' (2008) 6 London Review of Education 137 at 145, cited in A Wardrop, M Hutchings, B Collins, S Eccles, V Heaslip, C Hunt and C Pritchard 'Troubling ideas for widening participation: how higher education institutions in England engage with research in their access agreements' (2016) 18 Widening Participation and Lifelong Learning 84 at 90.

${ }^{77}$ Sommerlad, above n 12 , at 2331.

${ }^{78}$ Ibid, at 2327, citing PA Williams, The Alchemy of Race and Rights, (Cambridge, MA: Harvard University Press, 1991) p 99.

${ }^{79}$ Sommerlad, above n 12, at 2347.
} 


\section{Appendix 1 - Data Tables: Oxford and Cambridge}

Maximum percentage of eligible staff included (rounded to the nearest 5\%):

Oxbridge $1-75 \%$

Oxbridge $2-70 \%$

Oxbridge Table 1

\begin{tabular}{|c|c|c|c|c|c|c|}
\hline Institution & $\begin{array}{l}\text { Bachelor's } \\
\text { degree } \\
\text { Cambridge \% }\end{array}$ & $\begin{array}{l}\text { Bachelor's } \\
\text { degree } \\
\text { Oxford \% }\end{array}$ & $\begin{array}{l}\text { Bachelor's } \\
\text { degree } \\
\text { Russell } \\
\text { Group \% }\end{array}$ & $\begin{array}{l}\text { Bachelor's } \\
\text { degree } \\
\text { pre-1992 } \\
\text { (not Russell } \\
\text { Group) \% }\end{array}$ & $\begin{array}{l}\text { Bachelor's } \\
\text { degree } \\
\text { Polytechnic/ } \\
\text { CNAA }^{1} / \\
\text { post-1992\% }\end{array}$ & $\begin{array}{l}\text { Bachelor's } \\
\text { degree or } \\
\text { equivalent } \\
\text { non-UK \% }\end{array}$ \\
\hline Oxbridge 1 & 31 & 14 & 8 & 2 & 0 & 29 \\
\hline Oxbridge 2 & 12 & 37 & 7 & 3 & 1 & 32 \\
\hline Totals (\% mean) & 21.5 & 25.5 & 7.5 & 2.5 & 0.5 & 30.5 \\
\hline
\end{tabular}

notes: ${ }^{1}$ The Council for National Academic Awards (CNAA) was the largest degree-awarding body in the UK. There were over 140 institutions, including polytechnics and other higher education institutions, offering courses approved by the CNAA. CNAA awards are deemed comparable to those of universities. The CNAA was abolished by the Further and Higher Education Act 1992. For further details, see website available at http://www.open.ac.uk/cicp/main/validation/awards-and-aftercare/cnaa-pro-forma-verification/about-cnaa\#.

Oxbridge Table 2

\begin{tabular}{|c|c|c|c|c|c|c|}
\hline Institution & $\begin{array}{l}\text { Master's } \\
\text { degree } \\
\text { Cambridge \% }\end{array}$ & $\begin{array}{l}\text { Master's } \\
\text { degree or } \\
\text { equivalent } \\
\text { Oxford \% }\end{array}$ & $\begin{array}{l}\text { Master's } \\
\text { degree } \\
\text { Russell } \\
\text { Group \% }\end{array}$ & $\begin{array}{l}\text { Master's } \\
\text { degree } \\
\text { pre-1992 } \\
\text { (not Russell } \\
\text { Group) \% }\end{array}$ & $\begin{array}{l}\text { Master's } \\
\text { degree } \\
\text { Polytechnic/ } \\
\text { CNAA/ } \\
\text { post-1992 \% }\end{array}$ & $\begin{array}{l}\text { Master's } \\
\text { degree or } \\
\text { equivalent } \\
\text { non-UK \% }\end{array}$ \\
\hline Oxbridge 1 & 19 & 13 & 6 & 3 & 0 & 28 \\
\hline Oxbridge 2 & 5 & 45 & 6 & 0 & 0 & 24 \\
\hline Totals (\% mean) & 12 & 29 & 6 & 1.5 & 0 & 26 \\
\hline
\end{tabular}

Oxbridge Table 3

\begin{tabular}{lcccccc}
\hline Institution & $\begin{array}{l}\text { Doctorate } \\
\text { Cambridge } \%\end{array}$ & $\begin{array}{l}\text { Doctorate } \\
\text { Oxford \% }\end{array}$ & $\begin{array}{l}\text { Doctorate } \\
\text { Russell } \\
\text { Group } \%\end{array}$ & $\begin{array}{l}\text { Doctorate } \\
\text { pre-1992 } \\
\text { (not Russell } \\
\text { Group) \% }\end{array}$ & $\begin{array}{l}\text { Doctorate } \\
\text { Polytechnic/ } \\
\text { CNAA/ } \\
\text { post-1992 \% }\end{array}$ & $\begin{array}{l}\text { Doctorate or } \\
\text { equivalent } \\
\text { non-UK \% }\end{array}$ \\
\hline Oxbridge 1 & 44 & 10 & 4 & 0 & 0 & 12 \\
\hline Oxbridge 2 & 4 & 36 & 4 & 1 & 0 & 10 \\
\hline Totals (\% mean) & 24 & 23 & 4 & 0.5 & 0 & 11 \\
\hline
\end{tabular}


Oxbridge Table 4

\begin{tabular}{|c|c|c|c|c|c|c|c|c|c|}
\hline $\begin{array}{l}\text { Institution (\% of } \\
\text { eligible faculty } \\
\text { included) }\end{array}$ & $\begin{array}{l}\text { No } \\
\text { doctorate } \\
\text { (senior/long } \\
\text { experience) } \\
\%\end{array}$ & $\begin{array}{l}\text { No doctorate } \\
\text { (mid-career) \% }\end{array}$ & $\begin{array}{l}\text { No doctorate } \\
\text { (early career) \% }\end{array}$ & $\begin{array}{l}\text { Previous } \\
\text { academic role } \\
\text { - Oxbridge } \%\end{array}$ & $\begin{array}{l}\text { Previous } \\
\text { academic } \\
\text { role - Russell } \\
\text { Group \% }\end{array}$ & $\begin{array}{l}\text { Previous } \\
\text { academic } \\
\text { role - } \\
\text { pre-1992 } \\
\text { (not } \\
\text { Russell } \\
\text { Group) \% }\end{array}$ & $\begin{array}{l}\text { Previous } \\
\text { academic } \\
\text { role - } \\
\text { Polytechnic/ } \\
\text { post } 1992 \%\end{array}$ & $\begin{array}{l}\text { Previous } \\
\text { academic } \\
\text { role - } \\
\text { non-UK }\end{array}$ & $\begin{array}{l}\text { Professional } \\
\text { Qualification } \\
\text { (Solicitor/ } \\
\text { Barrister or } \\
\text { non-UK } \\
\text { equivalent) \% }\end{array}$ \\
\hline Oxb 1 & 15 & 1 & 0 & 10 & 17 & 4 & 0 & 15 & 22 \\
\hline Oxb 2 & 32 & 3 & 0 & 13 & 40 & 9 & 3 & 21 & 36 \\
\hline Totals (\% mean) & 23.5 & 2 & 0 & 11.5 & 28.5 & 6.5 & 1.5 & 18 & 29 \\
\hline
\end{tabular}

notes: ${ }^{2}$ For the purposes of the Oxford and Cambridge data this category relates to those academics who have worked at the other institution, not to moves between colleges within one institution. 


\section{Appendix 2 - Data tables: Russell Group (Excluding Oxford and Cambridge) Sample}

Maximum percentage of eligible staff included (rounded to the nearest 5\%):

\begin{tabular}{l}
\hline RG 1 \\
$85 \%$ \\
\hline RG 2 \\
$75 \%$ \\
\hline RG 3 \\
$85 \%$ \\
\hline RG 4 \\
$80 \%$ \\
\hline RG 5 \\
$75 \%$ \\
\hline$R G 6$ \\
$85 \%$ \\
\hline$R G 7$ \\
$70 \%$ \\
\hline$R G 8$ \\
$80 \%$ \\
\hline
\end{tabular}

RG Table 1

\begin{tabular}{|c|c|c|c|c|c|c|}
\hline Institution & $\begin{array}{l}\text { Bachelor's } \\
\text { degree } \\
\text { Cambridge \% }\end{array}$ & $\begin{array}{l}\text { Bachelor's } \\
\text { degree } \\
\text { Oxford \% }\end{array}$ & $\begin{array}{l}\text { Bachelor's } \\
\text { degree } \\
\text { Russell } \\
\text { Group \% }\end{array}$ & $\begin{array}{l}\text { Bachelor's } \\
\text { degree } \\
\text { pre-1992 } \\
\text { (not Russell } \\
\text { Group) \% }\end{array}$ & $\begin{array}{l}\text { Bachelor's } \\
\text { degree } \\
\text { Polytechnic/ } \\
\text { CNAA/ } \\
\text { post-1992\% }\end{array}$ & $\begin{array}{l}\text { Bachelor's } \\
\text { degree or } \\
\text { equivalent } \\
\text { non-UK \% }\end{array}$ \\
\hline RG 1 & 0 & 4 & 42 & 18 & 1 & 40 \\
\hline RG 2 & 8 & 19 & 35 & 19 & 2 & 16 \\
\hline RG 3 & 3 & 0 & 23 & 18 & 5 & 51 \\
\hline RG 4 & 4 & 9 & 30 & 15 & 6 & 21 \\
\hline RG 5 & 8 & 16 & 28 & 2 & 0 & 44 \\
\hline RG 6 & 3 & 5 & 37 & 16 & 0 & 37 \\
\hline RG 7 & 2 & 11 & 28 & 9 & 2 & 40 \\
\hline RG 8 & 20 & 10 & 55 & 5 & 0 & 10 \\
\hline Totals (\% mean) & 6 & 9.3 & 34.8 & 12.8 & 2 & 32.4 \\
\hline
\end{tabular}


RG Table 2

\begin{tabular}{|c|c|c|c|c|c|c|}
\hline Institution & $\begin{array}{l}\text { Master's } \\
\text { degree } \\
\text { Cambridge \% }\end{array}$ & $\begin{array}{l}\text { Master's } \\
\text { degree or } \\
\text { equivalent } \\
\text { Oxford \% }\end{array}$ & $\begin{array}{l}\text { Master's } \\
\text { degree } \\
\text { Russell } \\
\text { Group \% }\end{array}$ & $\begin{array}{l}\text { Master's } \\
\text { degree } \\
\text { pre-1992 } \\
\text { (not Russell } \\
\text { Group) \% }\end{array}$ & $\begin{array}{l}\text { Master's } \\
\text { degree } \\
\text { Polytechnic/ } \\
\text { CNAA/ } \\
\text { post-1992\% }\end{array}$ & $\begin{array}{l}\text { Master's } \\
\text { degree or } \\
\text { equivalent } \\
\text { non-UK \% }\end{array}$ \\
\hline RG 1 & 2 & 4 & 40 & 18 & 6 & 14 \\
\hline RG 2 & 8 & 16 & 32 & 3 & 0 & 12 \\
\hline RG 3 & 15 & 3 & 49 & 5 & 0 & 23 \\
\hline RG 4 & 4 & 13 & 30 & 6 & 2 & 19 \\
\hline RG 5 & 4 & 20 & 16 & 2 & 0 & 36 \\
\hline RG 6 & 5 & 5 & 34 & 3 & 0 & 26 \\
\hline RG 7 & 0 & 2 & 36 & 4 & 2 & 23 \\
\hline RG 8 & 0 & 10 & 15 & 10 & 0 & 10 \\
\hline Totals (\% mean) & 4.8 & 9.1 & 31.5 & 6.4 & 1.3 & 20.4 \\
\hline
\end{tabular}

RG Table 3

\begin{tabular}{|c|c|c|c|c|c|c|}
\hline Institution & $\begin{array}{l}\text { Doctorate } \\
\text { Cambridge \% }\end{array}$ & $\begin{array}{l}\text { Doctorate } \\
\text { Oxford \% }\end{array}$ & $\begin{array}{l}\text { Doctorate } \\
\text { Russell } \\
\text { Group \% }\end{array}$ & $\begin{array}{l}\text { Doctorate } \\
\text { pre-1992 } \\
\text { (not Russell } \\
\text { Group) \% }\end{array}$ & $\begin{array}{l}\text { Doctorate } \\
\text { Polytechnic/ } \\
\text { CNAA/ } \\
\text { post-1992\% }\end{array}$ & $\begin{array}{l}\text { Doctorate or } \\
\text { equivalent } \\
\text { non-UK \% }\end{array}$ \\
\hline RG 1 & 6 & 4 & 54 & 14 & 0 & 10 \\
\hline RG 2 & 3 & 6 & 38 & 6 & 3 & 8 \\
\hline RG 3 & 0 & 8 & 38 & 8 & 3 & 15 \\
\hline RG 4 & 2 & 6 & 42 & 9 & 6 & 11 \\
\hline RG 5 & 20 & 18 & 26 & 2 & 0 & 26 \\
\hline RG 6 & 0 & 3 & 47 & 11 & 0 & 16 \\
\hline RG 7 & 4 & 4 & 32 & 11 & 2 & 21 \\
\hline RG 8 & 5 & 0 & 35 & 20 & 5 & 10 \\
\hline Totals (\% mean) & 5 & 6.1 & 39 & 10.1 & 2.4 & 14.6 \\
\hline
\end{tabular}


RG Table 4

\begin{tabular}{|c|c|c|c|c|c|c|c|c|c|}
\hline Institution & $\begin{array}{l}\text { No doctorate } \\
\text { (senior/long } \\
\text { experience) \% }\end{array}$ & $\begin{array}{l}\text { No doctorate } \\
\text { (mid-career) \% }\end{array}$ & $\begin{array}{l}\text { No } \\
\text { doctorate } \\
\text { (early } \\
\text { career) \% }\end{array}$ & $\begin{array}{l}\text { Previous } \\
\text { academic } \\
\text { role - } \\
\text { Oxbridge \% }\end{array}$ & $\begin{array}{l}\text { Previous } \\
\text { academic } \\
\text { role - Russell } \\
\text { Group \% }\end{array}$ & $\begin{array}{l}\text { Previous } \\
\text { academic role } \\
\text { - pre-1992 } \\
\text { (not Russell } \\
\text { Group) \% }\end{array}$ & $\begin{array}{l}\text { Previous } \\
\text { academic role - } \\
\text { Polytechnic/ } \\
\text { post } 1992 \%\end{array}$ & $\begin{array}{l}\text { Previous } \\
\text { academic } \\
\text { role - } \\
\text { non-UK }\end{array}$ & $\begin{array}{l}\text { Professional } \\
\text { Qualification } \\
\text { (solicitor/barrister } \\
\text { or non-UK } \\
\text { equivalent) }\end{array}$ \\
\hline RG 1 & 8 & 6 & 0 & 6 & 60 & 26 & 4 & 12 & 32 \\
\hline RG 2 & 16 & 6 & 0 & 2 & 33 & 18 & 0 & 6 & 19 \\
\hline RG 3 & 23 & 0 & 3 & 3 & 41 & 31 & 15 & 8 & 33 \\
\hline RG 4 & 21 & 6 & 0 & 2 & 38 & 32 & 9 & 11 & 30 \\
\hline RG 5 & 14 & 0 & 0 & 26 & 46 & 20 & 2 & 16 & 32 \\
\hline RG 6 & 18 & 3 & 0 & 0 & 21 & 21 & 3 & 8 & 37 \\
\hline RG 7 & 15 & 2 & 0 & 6 & 28 & 23 & 11 & 15 & 40 \\
\hline RG 8 & 25 & 10 & 0 & 20 & 35 & 40 & 30 & 20 & 60 \\
\hline $\begin{array}{l}\text { Totals ( } \% \\
\text { mean) }\end{array}$ & 17.5 & 4.1 & 0.4 & 8.1 & 37.8 & 26.4 & 9.3 & 12.0 & 35.4 \\
\hline
\end{tabular}




\section{Appendix 3 -Data Tables: Pre-1992 (Non-Russell Group) Sample}

Maximum percentage of eligible staff included (rounded to the nearest 5\%):

\begin{tabular}{l}
\hline Pre-1992(1) \\
$85 \%$ \\
\hline Pre-1992(2) \\
$85 \%$ \\
\hline Pre-1992(3) \\
$85 \%$ \\
\hline Pre-1992(4) \\
$90 \%$ \\
\hline Pre-1992(5) \\
$85 \%$ \\
\hline Pre-1992(6) \\
$85 \%$ \\
\hline Pre-1992(7) \\
$90 \%$ \\
\hline Pre-1992(8) \\
$65 \%$ \\
\hline
\end{tabular}

Pre-1992 Table 1

\begin{tabular}{|c|c|c|c|c|c|c|}
\hline Institution & $\begin{array}{l}\text { Bachelor's } \\
\text { degree } \\
\text { Cambridge \% }\end{array}$ & $\begin{array}{l}\text { Bachelor's } \\
\text { degree } \\
\text { Oxford \% }\end{array}$ & $\begin{array}{l}\text { Bachelor's } \\
\text { degree } \\
\text { Russell } \\
\text { Group \% }\end{array}$ & $\begin{array}{l}\text { Bachelor's } \\
\text { degree } \\
\text { pre-1992 } \\
\text { (not Russell } \\
\text { Group) \% }\end{array}$ & $\begin{array}{l}\text { Bachelor's } \\
\text { degree } \\
\text { Polytechnic/ } \\
\text { CNAA/ } \\
\text { post-1992 \% }\end{array}$ & $\begin{array}{l}\text { Bachelor's } \\
\text { degree or } \\
\text { equivalent } \\
\text { non-UK \% }\end{array}$ \\
\hline Pre-1992(1) & 3 & 0 & 14 & 17 & 0 & 66 \\
\hline Pre-1992(2) & 6 & 10 & 20 & 14 & 2 & 39 \\
\hline Pre-1992(3) & 0 & 0 & 26 & 33 & 7 & 33 \\
\hline Pre-1992(4) & 3 & 3 & 19 & 35 & 0 & 39 \\
\hline Pre-1992(5) & 4 & 5 & 27 & 20 & 11 & 40 \\
\hline Pre-1992(6) & 7 & 14 & 14 & 19 & 9 & 33 \\
\hline Pre-1992(7) & 13 & 10 & 10 & 3 & 3 & 61 \\
\hline Pre-1992(8) & 17 & 4 & 21 & 25 & 8 & 17 \\
\hline Totals (\% mean) & 6.6 & 5.8 & 18.9 & 20.8 & 5 & 41 \\
\hline
\end{tabular}


Pre-1992 Table 2

\begin{tabular}{|c|c|c|c|c|c|c|}
\hline Institution & $\begin{array}{l}\text { Master's } \\
\text { degree } \\
\text { Cambridge \% }\end{array}$ & $\begin{array}{l}\text { Master's } \\
\text { degree or } \\
\text { equivalent } \\
\text { Oxford \% }\end{array}$ & $\begin{array}{l}\text { Master's } \\
\text { degree } \\
\text { Russell } \\
\text { Group \% }\end{array}$ & $\begin{array}{l}\text { Master's degree } \\
\text { pre-1992 } \\
\text { (not Russell } \\
\text { Group) \% }\end{array}$ & $\begin{array}{l}\text { Master's degree } \\
\text { Polytechnic/ } \\
\text { CNAA/ } \\
\text { post-1992\% }\end{array}$ & $\begin{array}{l}\text { Master's } \\
\text { degree or } \\
\text { equivalent } \\
\text { non-UK \% }\end{array}$ \\
\hline Pre-1992(1) & 3 & 0 & 28 & 14 & 0 & 38 \\
\hline Pre-1992(2) & 4 & 0 & 29 & 20 & 0 & 20 \\
\hline Pre-1992(3) & 7 & 0 & 11 & 11 & 4 & 11 \\
\hline Pre-1992(4) & 6 & 6 & 19 & 23 & 0 & 32 \\
\hline Pre-1992(5) & 2 & 4 & 20 & 25 & 5 & 24 \\
\hline Pre-1992(6) & 2 & 19 & 26 & 23 & 2 & 19 \\
\hline Pre-1992(7) & 0 & 3 & 39 & 3 & 6 & 26 \\
\hline Pre-1992(8) & 0 & 0 & 25 & 21 & 0 & 17 \\
\hline Totals (\% mean) & 3 & 4 & 24.6 & 17.5 & 2.1 & 23.4 \\
\hline
\end{tabular}

Pre-1992 Table 3

\begin{tabular}{|c|c|c|c|c|c|c|}
\hline Institution & $\begin{array}{l}\text { Doctorate } \\
\text { Cambridge \% }\end{array}$ & $\begin{array}{l}\text { Doctorate } \\
\text { Oxford \% }\end{array}$ & $\begin{array}{l}\text { Doctorate } \\
\text { Russell } \\
\text { Group \% }\end{array}$ & $\begin{array}{l}\text { Doctorate } \\
\text { pre-1992 } \\
\text { (not Russell } \\
\text { Group) \% }\end{array}$ & $\begin{array}{l}\text { Doctorate } \\
\text { Polytechnic/ } \\
\text { CNAA/ } \\
\text { post-1992 \% }\end{array}$ & $\begin{array}{l}\text { Doctorate or } \\
\text { equivalent } \\
\text { non-UK \% }\end{array}$ \\
\hline Pre-1992(1) & 7 & 7 & 38 & 21 & 3 & 24 \\
\hline Pre-1992(2) & 6 & 2 & 12 & 33 & 0 & 18 \\
\hline Pre-1992(3) & 4 & 0 & 30 & 33 & 0 & 11 \\
\hline Pre-1992(4) & 0 & 3 & 23 & 23 & 0 & 19 \\
\hline Pre-1992(5) & 0 & 5 & 31 & 24 & 0 & 13 \\
\hline Pre-1992(6) & 0 & 7 & 33 & 21 & 2 & 12 \\
\hline Pre-1992(7) & 0 & 6 & 42 & 13 & 0 & 35 \\
\hline Pre-1992(8) & 8 & 0 & 17 & 25 & 8 & 4 \\
\hline Totals (\% mean) & 3.1 & 3.8 & 28.3 & 24.1 & 1.6 & 17 \\
\hline
\end{tabular}


Pre-1992 Table 4

\begin{tabular}{|c|c|c|c|c|c|c|c|c|c|}
\hline Institution & $\begin{array}{l}\text { No doctorate } \\
\text { (senior/long } \\
\text { experience) \% }\end{array}$ & $\begin{array}{l}\text { No doctorate } \\
\text { (mid-career) \% }\end{array}$ & $\begin{array}{l}\text { No } \\
\text { doctorate } \\
\text { (early } \\
\text { career) \% }\end{array}$ & $\begin{array}{l}\text { Previous } \\
\text { academic } \\
\text { role - } \\
\text { Oxbridge \% }\end{array}$ & $\begin{array}{l}\text { Previous } \\
\text { academic } \\
\text { role - } \\
\text { Russell } \\
\text { Group \% }\end{array}$ & $\begin{array}{l}\text { Previous } \\
\text { academic } \\
\text { role - } \\
\text { pre-1992 (not } \\
\text { Russell } \\
\text { Group) \% }\end{array}$ & $\begin{array}{l}\text { Previous } \\
\text { academic role } \\
\text { - Polytechnic/ } \\
\text { post } 1992 \%\end{array}$ & $\begin{array}{l}\text { Previous } \\
\text { academic } \\
\text { role - } \\
\text { non-UK }\end{array}$ & $\begin{array}{l}\text { Professional } \\
\text { Qualification } \\
\text { (solicitor/ } \\
\text { barrister or } \\
\text { non-UK } \\
\text { equivalent) }\end{array}$ \\
\hline Pre-1992(1) & 7 & 0 & 0 & 7 & 41 & 24 & 21 & 7 & 45 \\
\hline Pre-1992(2) & 16 & 2 & 0 & 0 & 24 & 15 & 14 & 12 & 27 \\
\hline Pre-1992(3) & 19 & 0 & 0 & 0 & 19 & 4 & 15 & 7 & 41 \\
\hline Pre-1992(4) & 23 & 0 & 3 & 6 & 32 & 19 & 13 & 16 & 32 \\
\hline Pre-1992(5) & 16 & 4 & 2 & 4 & 29 & 18 & 18 & 9 & 35 \\
\hline Pre-1992(6) & 14 & 2 & 0 & 5 & 21 & 19 & 14 & 9 & 42 \\
\hline Pre-1992(7) & 13 & 0 & 0 & 10 & 23 & 19 & 0 & 13 & 35 \\
\hline Pre-1992(8) & 25 & 0 & 0 & 4 & 17 & 17 & 17 & 17 & 38 \\
\hline Totals (\% mean) & 16.6 & 1 & 0.6 & 4.5 & 25.8 & 16.9 & 14 & 11.3 & 36.9 \\
\hline
\end{tabular}




\section{Appendix 4 - Data Tables: Post-1992 Sample}

Maximum percentage of eligible staff included (rounded to the nearest 5\%):

\begin{tabular}{l}
\hline Post-92(1) \\
$75 \%$ \\
\hline Post-92(2) \\
$60 \%$ \\
\hline Post-92(3) \\
$65 \%$ \\
\hline Post-92(4) \\
$70 \%$ \\
\hline Post-92(5) \\
$85 \%$ \\
\hline Post-92(6) \\
$60 \%$ \\
\hline Post-92(7) \\
$85 \%$ \\
\hline Post-92(8) \\
$85 \%$
\end{tabular}

Post-92 Table 1

\begin{tabular}{|c|c|c|c|c|c|c|}
\hline Institution & $\begin{array}{l}\text { Bachelor's } \\
\text { degree } \\
\text { Cambridge \% }\end{array}$ & $\begin{array}{l}\text { Bachelor's } \\
\text { degree } \\
\text { Oxford \% }\end{array}$ & $\begin{array}{l}\text { Bachelor's } \\
\text { degree } \\
\text { Russell } \\
\text { Group \% }\end{array}$ & $\begin{array}{l}\text { Bachelor's } \\
\text { degree } \\
\text { pre-1992 } \\
\text { (not Russell } \\
\text { Group) \% }\end{array}$ & $\begin{array}{l}\text { Bachelor's } \\
\text { degree } \\
\text { Polytechnic/ } \\
\text { CNAA/ } \\
\text { post-1992 \% }\end{array}$ & $\begin{array}{l}\text { Bachelor's } \\
\text { degree or } \\
\text { equivalent } \\
\text { non-UK \% }\end{array}$ \\
\hline Post-92(1) & 6 & 0 & 18 & 29 & 18 & 35 \\
\hline Post-92(2) & 5 & 10 & 25 & 20 & 35 & 10 \\
\hline Post-92(3) & 0 & 0 & 40 & 7 & 13 & 33 \\
\hline Post-92(4) & 0 & 0 & 18 & 9 & 64 & 18 \\
\hline Post-92(5) & 0 & 0 & 31 & 19 & 19 & 19 \\
\hline Post-92(6) & 7 & 7 & 28 & 22 & 38 & 13 \\
\hline Post-92(7) & 5 & 21 & 21 & 16 & 11 & 26 \\
\hline Post-92(8) & 4 & 8 & 40 & 8 & 20 & 20 \\
\hline Totals (\% mean) & 3.4 & 5.8 & 27.6 & 16.3 & 27.3 & 21.8 \\
\hline
\end{tabular}


Post-92 Table 2

\begin{tabular}{|c|c|c|c|c|c|c|}
\hline Institution & $\begin{array}{l}\text { Master's } \\
\text { degree } \\
\text { Cambridge \% }\end{array}$ & $\begin{array}{l}\text { Master's } \\
\text { degree or } \\
\text { equivalent } \\
\text { Oxford \% }\end{array}$ & $\begin{array}{l}\text { Master's } \\
\text { degree } \\
\text { Russell } \\
\text { Group \% }\end{array}$ & $\begin{array}{l}\text { Master's } \\
\text { degree } \\
\text { pre-1992 } \\
\text { (not } \\
\text { Russell } \\
\text { Group) \% }\end{array}$ & $\begin{array}{l}\text { Master's } \\
\text { degree } \\
\text { Polytechnic/ } \\
\text { CNAA/ } \\
\text { post-1992 \% }\end{array}$ & $\begin{array}{l}\text { Master's } \\
\text { degree or } \\
\text { equivalent } \\
\text { non-UK \% }\end{array}$ \\
\hline Post-92(1) & 0 & 0 & 18 & 35 & 18 & 29 \\
\hline Post-92(2) & 0 & 0 & 30 & 10 & 5 & 0 \\
\hline Post-92(3) & 0 & 0 & 20 & 7 & 7 & 20 \\
\hline Post-92(4) & 0 & 0 & 0 & 0 & 45 & 9 \\
\hline Post-92(5) & 6 & 0 & 56 & 25 & 0 & 6 \\
\hline Post-92(6) & 2 & 2 & 13 & 2 & 10 & 13 \\
\hline Post-92(7) & 11 & 11 & 32 & 5 & 11 & 11 \\
\hline Post-92(8) & 4 & 0 & 16 & 4 & 16 & 12 \\
\hline Totals (\% mean) & 2.9 & 1.6 & 23.1 & 11 & 14 & 12.5 \\
\hline
\end{tabular}

Post-92 Table 3

\begin{tabular}{|c|c|c|c|c|c|c|}
\hline Institution & $\begin{array}{l}\text { Doctorate } \\
\text { Cambridge \% }\end{array}$ & $\begin{array}{l}\text { Doctorate } \\
\text { Oxford \% }\end{array}$ & $\begin{array}{l}\text { Doctorate } \\
\text { Russell } \\
\text { Group \% }\end{array}$ & $\begin{array}{l}\text { Doctorate } \\
\text { pre-1992 } \\
\text { (not Russell } \\
\text { Group) \% }\end{array}$ & $\begin{array}{l}\text { Doctorate } \\
\text { Polytechnic/ } \\
\text { CNAA/ } \\
\text { post-1992\% }\end{array}$ & $\begin{array}{l}\text { Doctorate or } \\
\text { equivalent } \\
\text { non-UK \% }\end{array}$ \\
\hline Post-92(1) & 0 & 0 & 12 & 24 & 6 & 6 \\
\hline Post-92(2) & 0 & 0 & 25 & 10 & 10 & 0 \\
\hline Post-92(3) & 0 & 0 & 20 & 13 & 13 & 13 \\
\hline Post-92(4) & 0 & 0 & 9 & 9 & 0 & 9 \\
\hline Post-92(5) & 6 & 0 & 38 & 25 & 0 & 0 \\
\hline Post-92(6) & 2 & 0 & 13 & 2 & 5 & 7 \\
\hline Post-92(7) & 11 & 5 & 21 & 5 & 5 & 16 \\
\hline Post-92(8) & 4 & 0 & 12 & 0 & 4 & 0 \\
\hline Totals (\% mean) & 2.9 & 0.6 & 18.8 & 11 & 5.4 & 6.4 \\
\hline
\end{tabular}


Post-92 Table 4

\begin{tabular}{|c|c|c|c|c|c|c|c|c|c|}
\hline Institution & $\begin{array}{l}\text { No } \\
\text { doctorate } \\
\text { (senior/ } \\
\text { long } \\
\text { experience) } \\
\%\end{array}$ & $\begin{array}{l}\text { No } \\
\text { doctorate } \\
\text { (mid-career) } \\
\%\end{array}$ & $\begin{array}{l}\text { No } \\
\text { doctorate } \\
\text { (early } \\
\text { career) \% }\end{array}$ & $\begin{array}{l}\text { Previous } \\
\text { academic } \\
\text { role - } \\
\text { Oxbridge } \\
\%\end{array}$ & $\begin{array}{l}\text { Previous } \\
\text { academic } \\
\text { role - } \\
\text { Russell } \\
\text { Group \% }\end{array}$ & $\begin{array}{l}\text { Previous } \\
\text { academic } \\
\text { role - } \\
\text { pre-1992 } \\
\text { (not } \\
\text { Russell } \\
\text { Group) \% }\end{array}$ & $\begin{array}{l}\text { Previous } \\
\text { academic } \\
\text { role - } \\
\text { Polytechnic/ } \\
\text { post } 1992 \%\end{array}$ & $\begin{array}{l}\text { Previous } \\
\text { academic } \\
\text { role - } \\
\text { non-UK }\end{array}$ & $\begin{array}{l}\text { Professional } \\
\text { Qualification } \\
\text { (solicitor/ } \\
\text { barrister or } \\
\text { non-UK } \\
\text { equivalent) }\end{array}$ \\
\hline Post-92(1) & 47 & 12 & 0 & 0 & 18 & 24 & 35 & 18 & 71 \\
\hline Post-92(2) & 15 & 15 & 5 & 0 & 5 & 15 & 20 & 10 & 45 \\
\hline Post-92(3) & 33 & 0 & 0 & 7 & 20 & 13 & 40 & 7 & 60 \\
\hline Post-92(4) & 45 & 9 & 9 & 0 & 0 & 9 & 18 & 0 & 55 \\
\hline Post-92(5) & 25 & 0 & 0 & 0 & 31 & 0 & 13 & 0 & 19 \\
\hline Post-92(6) & 57 & 15 & 7 & 0 & 5 & 5 & 13 & 10 & 82 \\
\hline Post-92(7) & 26 & 11 & 0 & 11 & 21 & 26 & 26 & 16 & 42 \\
\hline Post-92(8) & 60 & 12 & 4 & 0 & 8 & 32 & 24 & 4 & 68 \\
\hline $\begin{array}{l}\text { Totals (\% } \\
\text { mean) }\end{array}$ & 38.5 & 9.3 & 3.1 & 2.3 & 13.5 & 15.5 & 23.6 & 8.1 & 55.3 \\
\hline
\end{tabular}

Cite this article: Davies M (2018). Educational background and access to legal academia. Legal Studies 38, 120-146. https:// doi.org/10.1017/1st.2017.5 